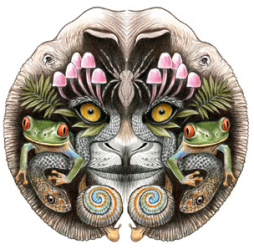

ISSN 0974-7907 (Online) ISSN $0974-7893$ (Print)

\title{
BIRDS OF SACRED GROVES OF NORTHERN KERALA, INDIA
}

\author{
K.M. Jyothi ${ }^{1}$ \& P.O. Nameer ${ }^{2}$
}

${ }^{1,2}$ Centre for Wildlife Sciences, College of Forestry, Kerala Agricultural University, Thrissur, Kerala 680656, India 1.jyokrish25@gmail.com, 2nameer.po@kau.in (corresponding author)

\section{OPEN ACCESS}

Abstract: Sacred groves are patches of vegetation preserved due to religious or cultural tradition. They are protected through spiritual beliefs. Sacred groves provide an excellent abode to the biodiversity of the region where they are located. Scientific exploration of fauna from sacred groves of India is few and far between. The present study was conducted to explore the bird diversity and abundance in 15 selected sacred groves of northern Kerala, eight from Kannur District and seven from Kasargod District each. A total of 111 bird species were observed belonging to 49 families and 16 orders. The sacred groves of northern Kerala support many of the 'forest-birds' such as the Grey Junglefowl Gallus sonneratii, Asian Fairy-bluebird Irena puella, Tickell's Blue-flycatcher Cyornis tickelliae, Malabar Trogon Harpactes fasciatus, Heart-spotted Woodpecker Hemicircus canente, Malabar Whistling-Thrush Myophonus horsfieldii, Little Spiderhunter Arachnothera longirostra, etc. The sacred groves of northern Kerala also support two endemic bird species of the Western Ghats, such as the Malabar Grey Hornbill Ocyceros griseus and Rufous Babbler Turdoides subrufa. Five species of raptors and four owl species were reported from the sacred groves of north Kerala during the present study. The breeding of the White-bellied Sea-Eagle has been reported at Edayilakadu Kavu, a sacred grove in Kasargod District. The sacred groves of northern Kerala also supported 17 species of long distant migratory birds. Thazhe Kavu, recorded the Black-headed Ibis Threskiornis melanocephalus, a Near-Threatened bird according to IUCN.

Keywords: Bird community, endemism, line transect method, migratory birds, point count, sacred groves, Western Ghats.

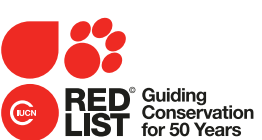

Sacred groves are age old luxuriant patches of vegetation preserved for deity (Gadgil \& Vartak 1974). They are protected through 'social fencing' (Khumbongmayum et al. 2005), rather than any law imposed by government for the protection of forests. It is believed that the cutting of trees or harming any animal in sacred groves leads to the wrath of the deity (Gadgil \& Vartak 1974; Dagal et al. 2007; Samati \& Gogoi 2007).

India is exceptionally rich in sacred groves with around 13,720 sacred groves spread across 19 States (Malhotra et al. 2001). The state of Kerala harbours 1500 to 2000 sacred groves, the extent of which varies from 0.004ha to $>20$ ha (Menon 1997). Induchoodan (1998) reported 361 sacred groves in Kerala having an area of more than 0.02 ha. Many small sacred groves have been lost in recent years and no recent data are available to assess their status.

Sacredgroves arelocallyknownas 'kavu' in Malayalam. There are different terminologies associated with the kavu depending upon the deity being worshipped at different sacred groves. These include 'Ayyappan Kavu' where the deity is lord Ayyappan, 'Bhagavathy Kavu' where the deity is goddess Bhagavathy, 'Muthappan Kavu' if the deity is Muthappan, incarnation of Lord

DOI: http://dx.doi.org/10.11609/jott.2463.7.15.8226-8236 | ZooBank: urn:Isid:zoobank.org:pub:3024A022-8718-410F-B143-408D61548F27

Editor: Anonymity requested.

Date of publication: 26 December 2015 (online \& print)

Manuscript details: Ms \# 04018 | Received 02 July 2014 | Final received 05 June 2015 | Finally accepted 08 November 2015

Citation: Jyothi, K.M. \& P.O. Nameer (2015). Birds of sacred groves of northern Kerala, India. Journal of Threatened Taxa 7(15): 8226-8236; http://dx.doi. org/10.11609/jott.2463.7.15.8226-8236

Copyright: () Jyothi \& Nameer 2015. Creative Commons Attribution 4.0 International License. JoTT allows unrestricted use of this article in any medium, reproduction and distribution by providing adequate credit to the authors and the source of publication.

Funding: Kerala Agricultural University.

Conflict of Interest: The authors declare no competing interests

Acknowledgements: We thank Neelesh Dahanukar and George Tom for the help with the data analysis, Sreehari, $R$, who prepared the map used in this paper and the anonymous reviewers for their critical comments which greatly improved the manuscript. We also thank the Dean, College of Forestry for the encouragement and support and the Kerala Agricultural University for the financial support for the conduct of the study. We acknowledge field assistance and the other help rendered by Lakshmy,A., Renisha,J.M., Jayasooryan, Devika,V.S., Navya T Nambiar, Sreekumar, E.R., Abha Manohar K, and Parvathy Venugopal. Sneha, C. and Vishnu, R. helped us in identifying the tree species in the sacred groves. The assistance and the support of the local trackers are also greatly acknowledged. We also thank the villagers of the study locations in Kannur and Kasargode for their excellent hospitality and co-operation. 
Shiva, and if the deity is a serpent it is called 'Sarpa Kavu', 'Naga Kavu' or 'Nagam'. There are also sacred groves dedicated to spirits, demons or ancestors called 'Yakshi Kavu' (Malhotra et al. 2001). Sacred groves are managed either by individual families, groups of families or by the statutory agencies for temple management, the Devaswom Boards (Chandrashekara \& Sankar 1998).

\section{Study AReA AND MethodS}

\section{Study area}

The present study was conducted at 15 sacred groves, eight in Kannur District and seven in Kasargod District of northern Kerala (Fig. 1).

\section{Methods}

The point count method as well as the line transect methods were used for studying the birds in the sacred groves (Bibby et al. 1992; Sashikumar 2004). For sacred groves that are less than 3 ha (small-sized sacred groves) the point count method was used, while the line transect method was used to study the birds in bigger sacred groves (>3ha). Out of the 15 sacred groves studied, five were small and 10 big.

All the birds that were encountered (including those heard) were recorded for three hours each from 07:00-10:00 hr and from 15:00-18:00 hr. The details recorded include species of birds, number of individuals and the distance from the point of observation. This bird count was repeated once every two months at each of the sacred groves for two years from March 2012 to December 2013.

The birds were identified using binoculars $(10 \times 50)$ and field guides of Ali \& Ripley (1987), Grimmett et al. (1998), Kazmierczak (2000), and Rasmussen \& Anderton (2012).

The relative abundance of bird species were worked out from encounter rates per 100 hours. Shannon index and Simpson index were calcutated to know species diversity and species richness. Bird species were categorised into resident $(R)$, migratory $(M)$, endemic $(\mathrm{E})$, forest edge (FE) and forest interior ( $\mathrm{FI}$ ) species. A resident species is one that is known to breed within Kerala's boundaries (Ali 1969; Sashikumar et al. 2011); migratory birds are ones that are non-breeding visitors to Kerala's limits (Grimmett \& Inskipp 2005); endemic are those that are restricted in distribution and confnied only to the Western Ghats; forest edge species are the ones that are seen in forest fringes and ecotones; while forest interior species are those that require pristine forests or a significant area of undisturbed forest (Sashikumar 2004). Birds were also assigned to various feeding guilds such as aerial (AER), aquatic (AQ), bark surface feeders (BAR), canopy insectivores (CAN), carnivores $(C A R)$, granivorous (GRA), frugivores (FRU), nectarivore-

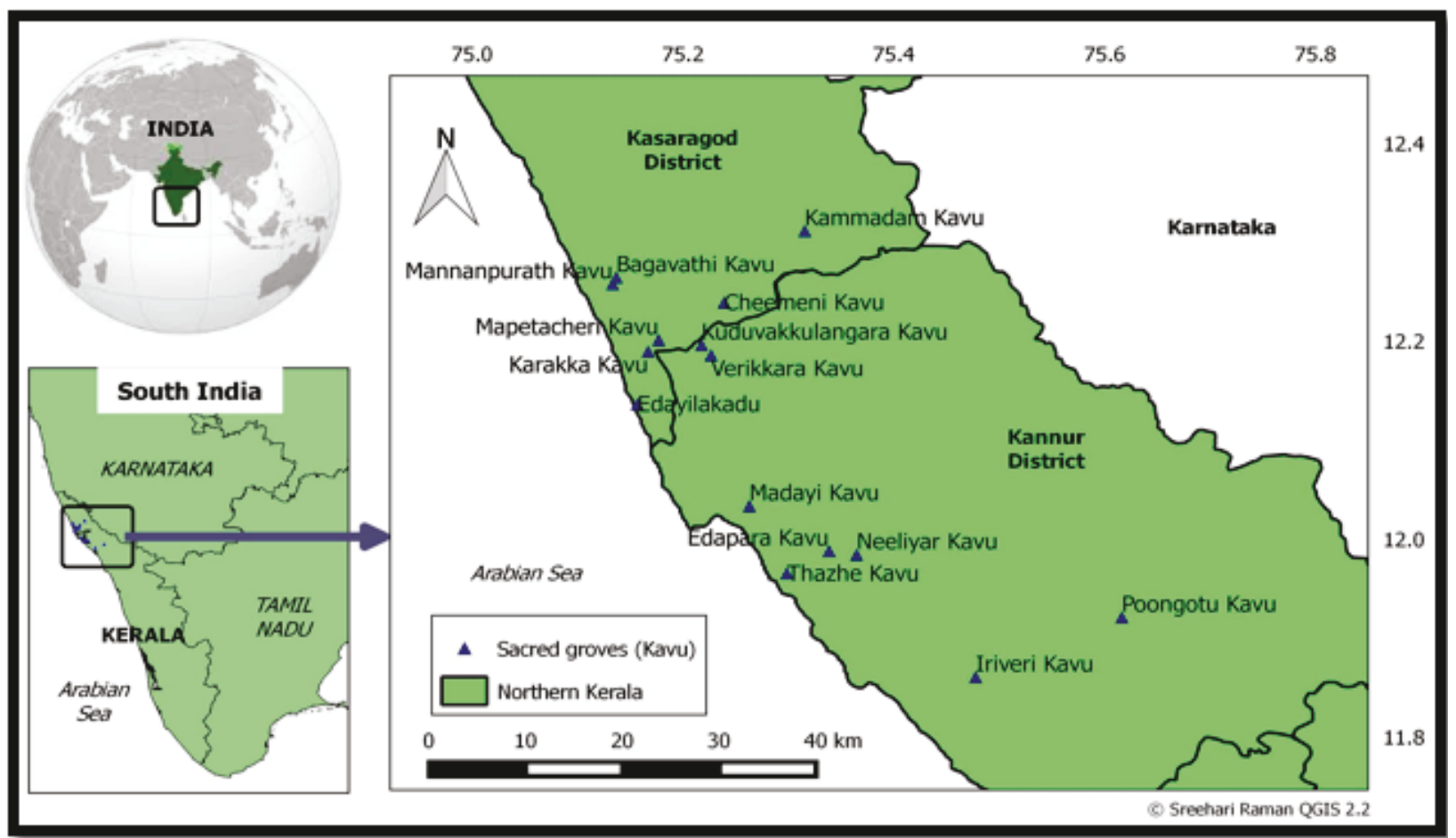

Figure 1. Study area in northern Kerala 
insectivores (NEC), omnivores (OMN), piscivores (PIS), terrestrial insectivores (TER), understory insectivores (UND), modified after Raman et al. (1998) and Praveen \& Nameer (2009). The whole two year long bird data per transect from the sacred groves of northern Kerala were uploaded into a web-based forum (www.ebird.org) for public access.

\section{Results AND Discussion Species Diversity Analysis}

A total of 107 bird species were observed belonging to 48 families and 17 orders in 15 selected sacred groves of Kannur and Kasargod districts of northern Kerala (Tables $1 \& 3$ ). As for the taxonomic sequence and English /scientific names we follow the IOC's World Checklist version 4.3 (Gill \& Donsker 2014). Highest species richness was found in Cheemeni Kavu (55) followed by Verikkara Kavu (54) and Mapetachery Kavu (46), while the maximum individuals of birds were seen at Thazhe Kavu (2237) followed by Mapetachery Kavu
(1926) and Madayi Kavu (1617). Bird species diversity was more in Cheemeni Kavu with a Shannon index of 1.51 and a Simpson index of 0.96 (Table 2). While the bird species diversity was lower at Edayilekadu having a Shannon index and Simpson index, 1.17 and 0.89 respectively. The maximum species diversity that was found in Cheemeni Kavu may have been due to the undisturbed condition of the sacred grove.

Twenty-five percent of the birds of the sacred groves of northern Kerala, were forest birds. These include Little Spiderhunter Arachnothera longirostra, Malabar Trogon Harpactes fasciatus, Malabar WhistlingThrush Myophonus horsfieldii, Grey Junglefowl Gallus sonneratii, Asian Fairy-bluebird Irena puella, Tickell's Blue-flycatcher Cyornis tickelliae, etc. (Ali 1969; Ripley 1982; Ali \& Ripley 1987; Rasmussen \& Anderton 2012). However, in an earlier study on the birds of sacred groves Sashikumar (2004) reported the occurrence of $50 \%$ of forest birds in the sacred groves of northern Kerala.

The sacred groves also support good populations of

Table 1. Study locations selected in northern Kerala

\begin{tabular}{|c|c|c|c|c|c|c|c|c|}
\hline & $\begin{array}{l}\text { Name of the } \\
\text { sacred grove }\end{array}$ & Co-ordinates & $\begin{array}{l}\text { Altitude } \\
\text { (m) }\end{array}$ & $\begin{array}{c}\text { Aerial Distance } \\
\text { from the reserve } \\
\text { forest }(\mathrm{km})\end{array}$ & $\begin{array}{c}\text { Area of } \\
\text { sacred } \\
\text { grove (ha) }\end{array}$ & Vegetation & $\begin{array}{l}\text { Neighbouring } \\
\text { vegetation }\end{array}$ & Water source \\
\hline 1 & $\begin{array}{l}\text { Kammadam Kavu } \\
\text { (Kasargod) }\end{array}$ & $\begin{array}{l}12^{\circ} 18^{\prime} 41.0^{\prime \prime} \mathrm{N} \& \\
75^{\circ} 18^{\prime} 55.8^{\prime \prime} \mathrm{E}\end{array}$ & 85 & 3.56 & 24.40 & $\begin{array}{l}\text { Evergreen with } \\
\text { fresh water } \\
\text { myristica swamp }\end{array}$ & $\begin{array}{l}\text { Rubber, banana, } \\
\text { coconut and areca } \\
\text { nut plantations }\end{array}$ & $\begin{array}{l}\text { Perennial } \\
\text { Stream }\end{array}$ \\
\hline 2 & $\begin{array}{l}\text { Bagavathi Kavu } \\
\text { (Kasargod) }\end{array}$ & $\begin{array}{l}12^{\circ} 15^{\prime} 51.84^{\prime \prime} \mathrm{N} \& \\
75^{\circ} 08^{\prime} 11.8^{\prime \prime} \mathrm{E}\end{array}$ & 8 & 16.50 & 1.92 & $\begin{array}{l}\text { Semi-evergreen } \\
\text { type }\end{array}$ & Homesteads & Well \\
\hline 3 & $\begin{array}{l}\text { Mannanpurath } \\
\text { Kavu (Kasargod) }\end{array}$ & $\begin{array}{l}12^{\circ} 15^{\prime} 27.6^{\prime \prime} \mathrm{N} \& \\
75^{\circ} 07^{\prime} 59.4^{\prime \prime} \mathrm{E}\end{array}$ & 8 & 17 & 2.80 & $\begin{array}{l}\text { Semi-evergreen } \\
\text { type }\end{array}$ & Homesteads & Pond \\
\hline 4 & $\begin{array}{l}\text { Cheemeni Kavu } \\
\text { (Kasargod) }\end{array}$ & $\begin{array}{l}12^{0} 14^{\prime} 20.7^{\prime \prime} \mathrm{N} \& \\
75^{\circ} 14^{\prime} 20.7^{\prime \prime} \mathrm{E}\end{array}$ & 99 & 11.30 & 4 & $\begin{array}{l}\text { Semi-evergreen } \\
\text { type }\end{array}$ & $\begin{array}{l}\text { Paddy fields and } \\
\text { homesteads }\end{array}$ & Pond \\
\hline 5 & $\begin{array}{l}\text { Mapetacheri Kavu } \\
\text { (Kasargod) }\end{array}$ & $\begin{array}{l}12^{\circ} 12^{\prime} 04.3^{\prime \prime} \mathrm{N} \& \\
75^{\circ} 10^{\prime} 36.8^{\prime \prime} \mathrm{E}\end{array}$ & 17 & 18 & 4 & Evergreen & $\begin{array}{l}\text { Paddy fields, } \\
\text { Homesteads }\end{array}$ & Pond \\
\hline 6 & $\begin{array}{l}\text { Karakka Kavu } \\
\text { (Kasargod) }\end{array}$ & $\begin{array}{l}12^{\circ} 11^{\prime} 22.2^{\prime \prime} \mathrm{N} \& \\
75^{\circ} 10^{\prime} 00.8^{\prime \prime} \mathrm{E}\end{array}$ & 19 & 20 & 3.05 & Evergreen & Homesteads & Pond \\
\hline 7 & $\begin{array}{l}\text { Kuduvakolangara } \\
\text { Kavu (Kasargod) }\end{array}$ & $\begin{array}{l}12^{\circ} 11^{\prime} 45.88^{\prime \prime} \mathrm{N} \& \\
75^{\circ} 13^{\prime} 03.24^{\prime \prime} \mathrm{E}\end{array}$ & 24 & 14 & 3.40 & Semi evergreen & Homesteads & Well \\
\hline 8 & $\begin{array}{l}\text { Verikkara Kavu } \\
\text { (Kannur) }\end{array}$ & $\begin{array}{l}12^{\circ} 11^{\prime} 08.6^{\prime \prime} \mathrm{N} \& \\
75^{\circ} 13^{\prime} 36.0^{\prime \prime} \mathrm{E}\end{array}$ & 20 & 17 & 4.40 & Moist deciduous & $\begin{array}{l}\text { Paddy field, rubber } \\
\text { plantation }\end{array}$ & $\begin{array}{l}\text { Rain-fed } \\
\text { stream and } \\
\text { Well }\end{array}$ \\
\hline 9 & $\begin{array}{l}\text { Edayilekadu } \\
\text { (Kasargod) }\end{array}$ & $\begin{array}{l}12^{\circ} 08^{\prime} 10.72^{\prime \prime} \mathrm{N} \& \\
75^{\circ} 09^{\prime} 23.88^{\prime \prime} \mathrm{E}\end{array}$ & 14 & 20 & 6.40 & Evergreen & $\begin{array}{l}\text { Paddy fields and } \\
\text { Homesteads }\end{array}$ & Pond \\
\hline 10 & $\begin{array}{l}\text { Madayi Kavu } \\
\text { (Kannur) }\end{array}$ & $\begin{array}{l}12^{\circ} 01^{\prime} 59.7^{\prime \prime} \mathrm{N} \& \\
75^{\circ} 15^{\prime} 46.5^{\prime \prime} \mathrm{E}\end{array}$ & 43 & 35 & 1.6 & Moist deciduous & $\begin{array}{l}\text { Homesteads and } \\
\text { Grassland }\end{array}$ & $\begin{array}{l}\text { Well and } \\
\text { rain-fed } \\
\text { stream }\end{array}$ \\
\hline 11 & $\begin{array}{l}\text { Edapara Kavu } \\
\text { (Kannur) }\end{array}$ & $\begin{array}{l}11^{0} 59^{\prime} 16.2^{\prime \prime} \mathrm{N} \& \\
75^{\circ} 20^{\prime} 18.7^{\prime \prime} \mathrm{E}\end{array}$ & 16 & 11.30 & 2.80 & Semi evergreen & $\begin{array}{l}\text { Cashew Plantation } \\
\text { and homesteads }\end{array}$ & Well \\
\hline 12 & $\begin{array}{l}\text { Neeliyar Kavu } \\
\text { (Kannur) }\end{array}$ & $\begin{array}{l}11^{\circ} 59^{\prime} 02.6^{\prime \prime} \mathrm{N} \\
75^{\circ} 21^{\prime} 53.1^{\prime \prime} \mathrm{E}\end{array}$ & 31 & 30 & 8.07 & Evergreen & Homesteads & Wells \\
\hline 13 & $\begin{array}{l}\text { Thazhe Kavu } \\
\text { (Kannur) }\end{array}$ & $\begin{array}{l}11^{0} 57^{\prime} 54.6^{\prime \prime} \mathrm{N} \& \\
75^{\circ} 17^{\prime} 54.5^{\prime \prime} \mathrm{E}\end{array}$ & 3 & 38 & 7.52 & Mangrove & Paddy fields & $\begin{array}{l}\text { Well and } \\
\text { pond }\end{array}$ \\
\hline 14 & $\begin{array}{l}\text { Poongotu Kavu } \\
\text { (Kannur) }\end{array}$ & $\begin{array}{l}11^{\circ} 55^{\prime} 14.7^{\prime \prime} \mathrm{N} \& \\
75^{\circ} 36^{\prime} 58.9^{\prime \prime} \mathrm{E}\end{array}$ & 90 & 13 & 14.60 & $\begin{array}{l}\text { Fresh water } \\
\text { myristica swamp }\end{array}$ & $\begin{array}{l}\text { Rubber plantation, } \\
\text { homesteads, paddy } \\
\text { field }\end{array}$ & $\begin{array}{l}\text { Perennial } \\
\text { Stream }\end{array}$ \\
\hline 15 & $\begin{array}{l}\text { Iriveri Kavu } \\
\text { (Kannur) }\end{array}$ & $\begin{array}{l}11^{0} 51^{\prime} 36.9^{\prime \prime} \mathrm{N} \& \\
75^{\circ} 28^{\prime} 39.4^{\prime \prime} \mathrm{E}\end{array}$ & 42 & 18 & 2.12 & Semi evergreen & Homestead & Pond \\
\hline
\end{tabular}


Table 2. Bird species richness and diversity in the sacred groves of northern Kerala.

\begin{tabular}{|c|c|c|c|c|c|c|c|c|c|c|c|c|c|c|c|}
\hline Camp & 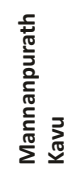 & 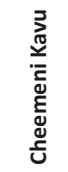 & 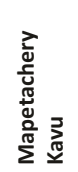 & 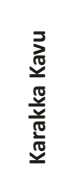 & 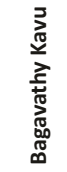 & $\begin{array}{l}\frac{3}{0} \\
\frac{\pi}{\pi} \\
\frac{\pi}{\pi} \\
\frac{\pi}{\sqrt{\pi}} \\
\frac{0}{4}\end{array}$ & 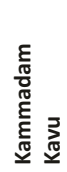 & 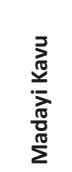 & 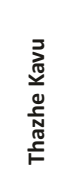 & 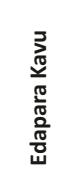 & 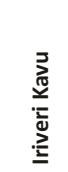 & 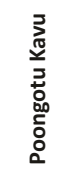 & 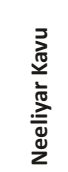 & 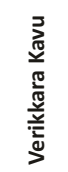 & 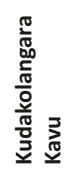 \\
\hline $\begin{array}{l}\text { No of } \\
\text { Species }\end{array}$ & 35 & 55 & 46 & 40 & 23 & 31 & 44 & 43 & 42 & 36 & 36 & 36 & 32 & 54 & 37 \\
\hline Abundance & 1069 & 1926 & 1249 & 1464 & 866 & 1224 & 1236 & 1617 & 2237 & 1282 & 1200 & 827 & 1316 & 1738 & 1574 \\
\hline $\begin{array}{l}\text { Shannon } \\
\text { Index (log } \\
\text { base } 10)\end{array}$ & 1.33 & 1.51 & 1.40 & 1.36 & 1.19 & 1.17 & 1.45 & 1.43 & 1.36 & 1.34 & 1.27 & 1.32 & 1.28 & 1.39 & 1.42 \\
\hline $\begin{array}{l}\text { Simpson } \\
\text { Index (D) }\end{array}$ & 0.06 & 0.04 & 0.05 & 0.06 & 0.08 & 0.11 & 0.05 & 0.05 & 0.06 & 0.06 & 0.09 & 0.07 & 0.08 & 0.07 & 0.05 \\
\hline $\begin{array}{l}\text { Inverse } \\
\text { Simpson } \\
\text { Index (1/D) }\end{array}$ & 16.66 & 23.19 & 18.42 & 17.52 & 12.78 & 9.08 & 20.17 & 18.25 & 17.36 & 16.77 & 11.73 & 14.77 & 13.32 & 14.16 & 21.16 \\
\hline $\begin{array}{l}\text { Gini Simpson } \\
\text { Index (1-D) }\end{array}$ & 0.94 & 0.96 & 0.95 & 0.94 & 0.92 & 0.89 & 0.95 & 0.95 & 0.94 & 0.94 & 0.91 & 0.93 & 0.92 & 0.93 & 0.95 \\
\hline
\end{tabular}

the birds of prey belonging to the families Acciptridae and Strigidae. Five species of raptors and four species of owls were recorded during the present study, while Sashikumar (2004) reported seven species of raptors and five species of owls.

Edayilekadu sacred grove acted as the nesting site for the White-bellied Sea-Eagle Haliaeetus leucogaster, the breeding of which was reported from the area in 2000 (Palot 2011), and it may be considered as a good sign that this species continues to breed at this sacred grove even now. Nocturnal birds of prey sighted were Brown Fish-Owl Bubo zeylonensis, Mottled Wood-Owl Strix ocellata, Brown Wood-Owl Strix leptogrammica and Spotted Owlet Athene brama. Sashikumar (2004), Deb et al. (1997) and Deb (2007) opined that sacred groves provide a habitat for the roosting and nesting of many raptors.

It is interesting to note that all 15 sacred groves supported migratory birds and 13 species were sighted during the present study (Table 3). Sacred groves also help in the conservation of endemic birds; in the present study two species endemic to the Western Ghats were observed. The Malabar Grey Hornbill was sighted from Kammadam Kavu and Poongotu Kavu, while Rufous Babblers were found at Kammadam Kavu, Kuduvakolangara Kavu and Verikkara Kavu.

Sashikumar (2004) however had reported four species of endemic birds from the sacred groves of northern Kerala. Apart from the above two species, he reported the presence of the Grey-headed Bulbul Pycnonotus priocephalus and the Small Sunbird Leptocoma minima,

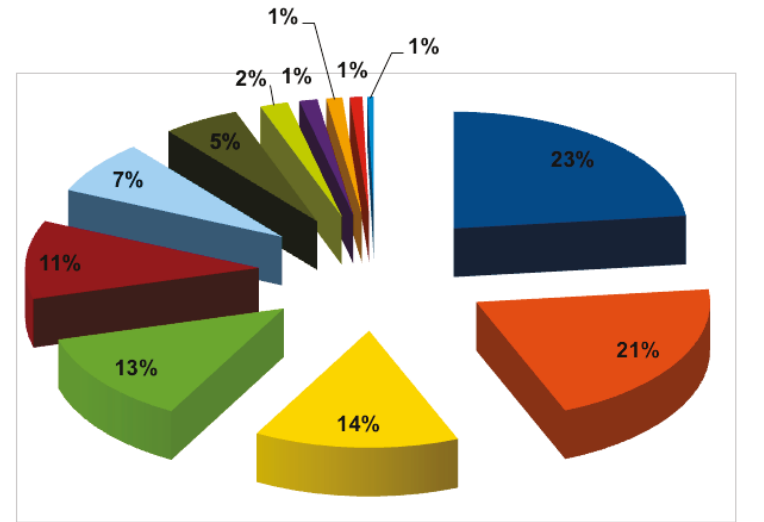

-CAN $=\mathrm{FRU}=\mathrm{OMN}=\mathrm{UND}=\mathrm{NEC}=\mathrm{CAR}=\mathrm{AQ}=\mathrm{GRA}$-PIS $=\mathrm{TER}=\mathrm{BAR}=\mathrm{AER}$

Figure 2. Overall Feeding guild structure of birds in the sacred grove of northern Kerala

which we did not sight during the present study. The sacred groves also support threatened bird species. The Thazhe Kavu, recorded the Black-headed Ibis Threskiornis melanocephalus, a Near-Threatened bird according to IUCN Red List of Threatened Species.

\section{Feeding guild structure}

The overall feeding guild structure is given in Fig. 2 and the feeding guild details of the different sacred groves are given in Fig. 2. Canopy insectivores and frugivores were the dominant feeding guilds accounting for $23 \%$ and $21 \%$, respectively while Omnivorous, Understorey 

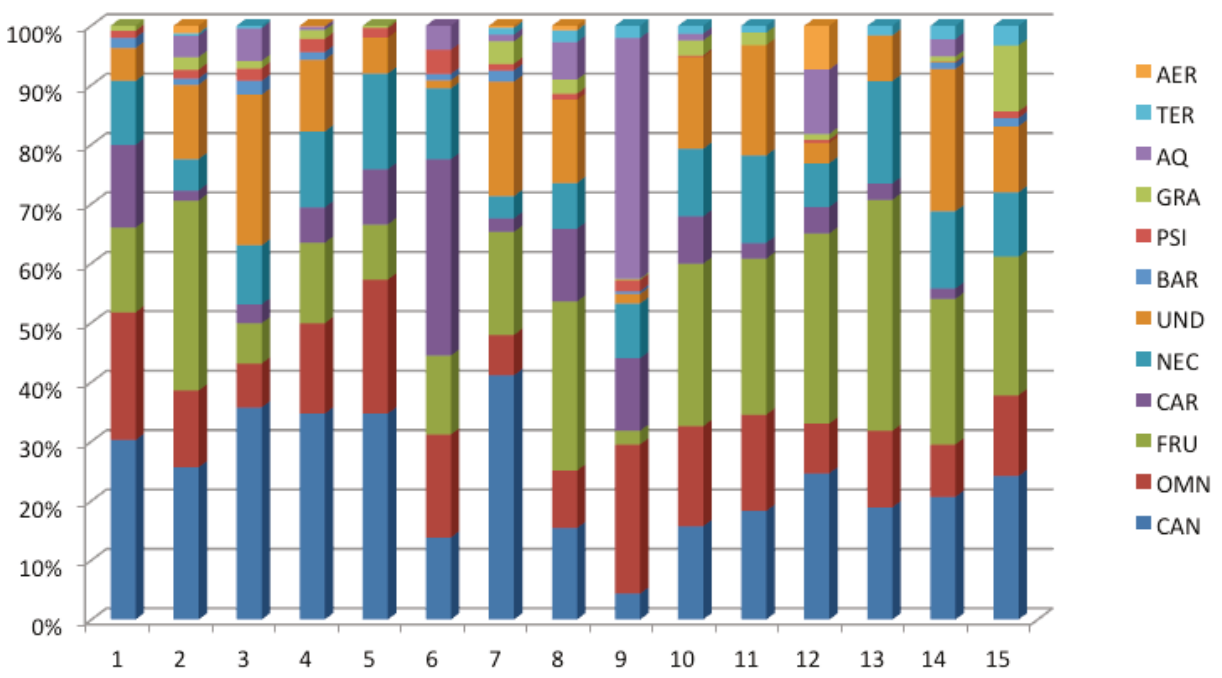

Figure 3. Feeding guild structure in the sacred groves of northern Kerala

dependants and nectarivorous-insectivorous feeding guilds accounted for $14 \%, 13 \%$ and $11 \%$ respectively.

\section{CONCLUSION}

Social fencing of sacred groves provides excellent protection to the biodiversity of the locality; they help in supporting diverse species of birds, including raptors, owls, forest birds, endemic birds, threatened birds as well as migratory birds. The results of the present study thus signifies the importance of the sacred groves in bird conservation. These small repositories of biodiversity should be conserved at any cost. Many of these sacred groves are under different kinds of threats such as dumping of waste including plastic, encroachment, people extensively using the trails passing through the sacred groves as short-cuts to their destination and general quality deterioration due to the urbanisation of the surrounding areas. Unless urgent steps are taken towards the conservation of these crucial island repositories of biodiversity, we might lose them in the near to medium-term future. This could also lead to socio-cultural and environmental problems.

\section{REFERENCES}

Ali, S. \& D.S. Ripley (eds.). (1987). Compact handbook of birds of India and Pakistan. Oxford University Press, 737pp.

Ali, S. (1969). Birds of Kerala. OUP, New Delhi, 404pp.

Bibby, C., N.D. Burgess \& D.A. Hill (1992). Bird Census Techniques. The British trust for ornithology and the royal society for the protection of birds, 66-104pp.

Chandrashekara, U.M. \& S. Sankar (1998). Ecology and Management of sacred groves in Kerala, India, Forest Ecology and Management 112: 165-177.

Dagal, H.R., A. Paliwal \& N.S. Shekhawat (2007). Oran: A sacred way for biodiversity conservation in Indian Thar Desert. Current Science 93(3): 279-280.

Deb, D. (2007). Sacred Groves of West Bengall: A Modell of Communiity Forest Management. Understanding Livelihood Impacts of Participatory Forest Management Implementation in India and Nepal Working Paper No. 8, 1-37pp.

Deb, D., K. Deuti \& K.C. Malhotra (1997). Sacred grove relic as bird refugia, Current Science 73(10): 279-280.

Gadgil, M. \& V.D. Vartak (1974). Sacred groves of India-a plea for continued conservation. Bombay Natural History Society 72(2): 313-320.

Gill, F. \& D. Donsker (Eds.) (2014). IOC World Bird List (v 4.3); http:// dx.doi.org/10.14344/IOC.ML.4.3

Grimmett, R. C. Inskipp \& T. Inskipp (1998). Birds of the Indian Subcontinent. Oxford University Press, New Delhi, 888pp.

Grimmett, R. \& T. Inskipp (2005). Birds of Southern India. Om book International, New Delhi, 240pp.

Induchoodan, N.C. (1998). Ecological Studies of the Sacred Groves of Kerala. PhD Thesis. Central University, Pondicherry.

Kazmierczak, K. (2000). A Field Guide to the Birds of Indian Subcontinent. Helm Information Ltd., U.K.

Khumbongmayum, A., M.L. Khan \& R.S. Tripathi (2005). Survival and growth of seedlings of a few tree species in the four sacred groves of Manipur, northeast, India. Current Science 88(11): 1781-1788.

Malhotra, K.C., Y. Gokhale, S. Chatterjee \& S. Srivastava (2001). Cultural and Ecological Dimensions of Sacred Groves in India. Indian National Science Academy, New Delhi and Indira Gandhi Rashtriya Manav Sangrahalaya, Bhopal, 16-17pp.

Menon, S.V. (1997). Sacred groves, pp. 159-167. In: Thampi, K., N.M. Nayar \& G.S. Nair (eds.). The Natural Resources of Kerala. World Wide Fund for Nature-India, Thiruvananthapuram, 567pp.

Palot, M.J. (2011). Status and Conservation of White-bellied Sea Eagle, Haliaeetus leucogaster (Gmelin) in Kerala, pp. 267. In: Bhupathy, S., B.A.K. Prusty, H.N. Kumara, R.S.C. Jayaraj, G. Quadros \& P. Pramod (eds.). Status of Indian Birds and their Conservation. Proceedings of the First International Conference on Indian Ornithology, 19-23 November, 2011. Salim Ali Centre for Ornithology and Natural History, Coimbatore, India, 301pp.

Praveen, J. \& P.O. Nameer (2009). Monitoring bird diversity in Western Ghats of Kerala. Current Science 96(10): 1390-1395.

Raman, T.R.S., G.S. Rawat \& A.J.T. Johnsingh (1998). Recovery of Tropical rain forest avifauna in relation to vegetation succession following shifting cultivation in Mizoram. North-east India. Journal of Applied Ecology 25: 214-231. 


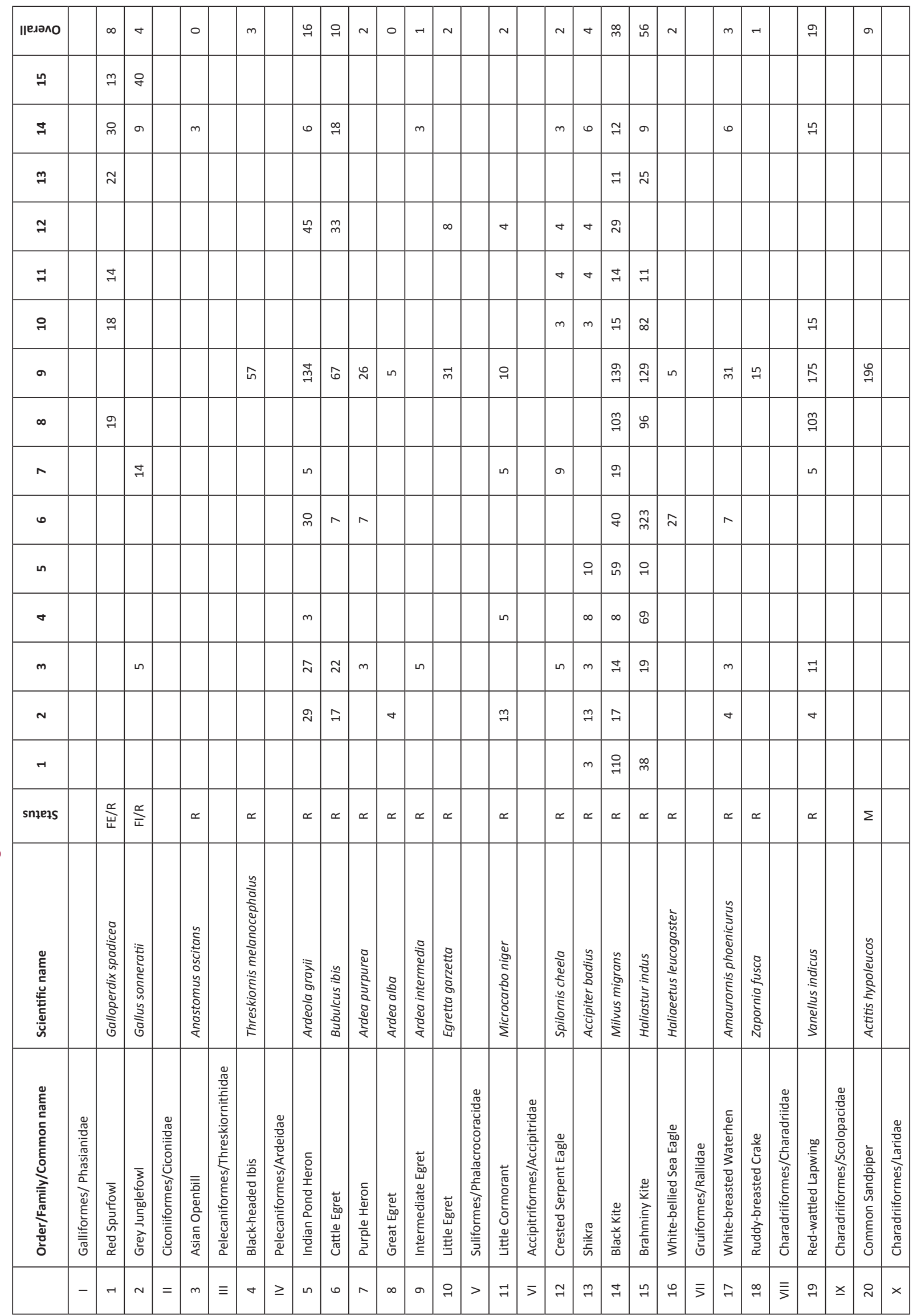




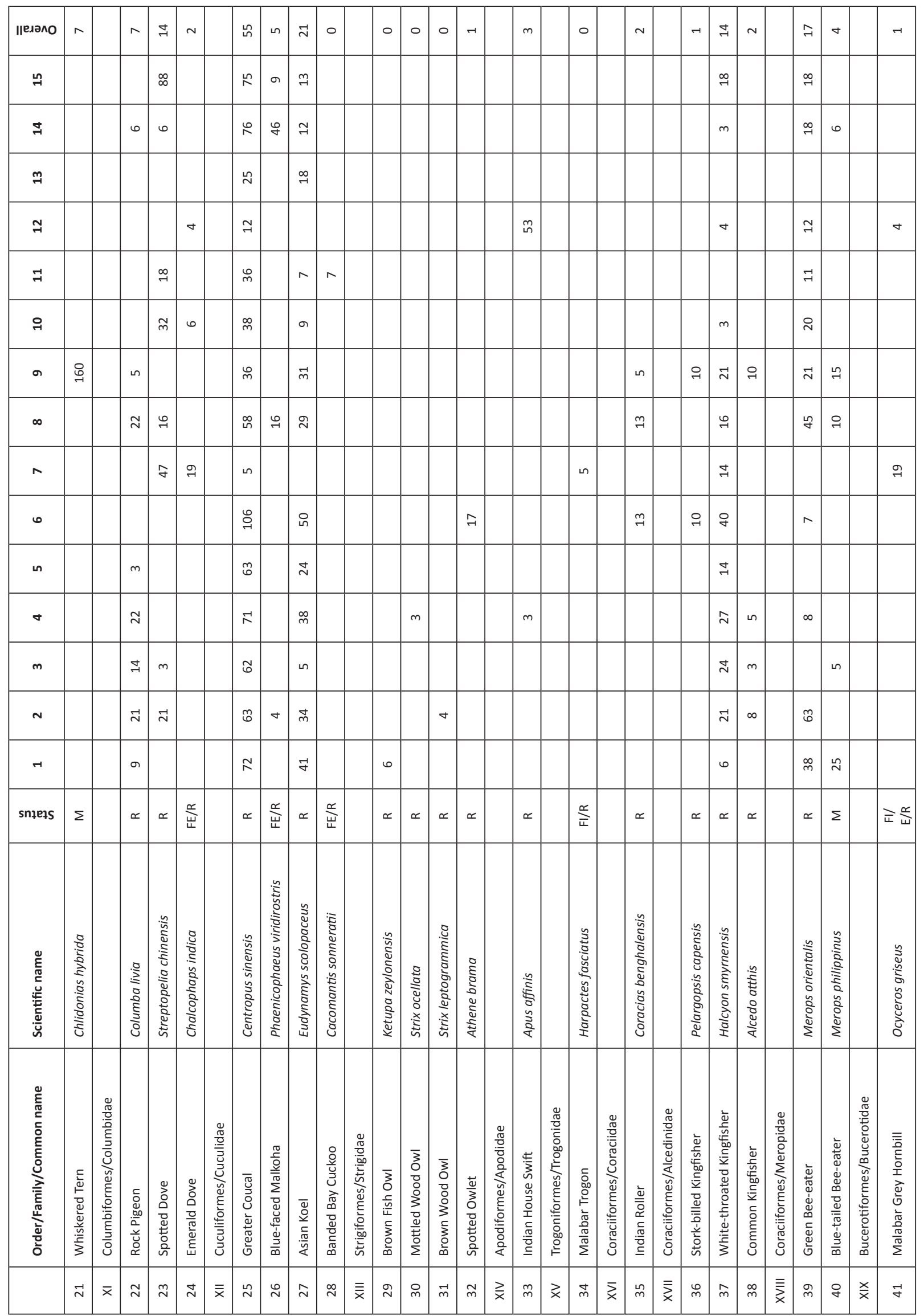




\begin{tabular}{|c|c|c|c|c|c|c|c|c|c|c|c|c|c|c|c|c|c|c|c|c|}
\hline ॥едәло & 5 & - & $\sim$ & $\sigma$ & 0 & 0 & $m$ & $\stackrel{\infty}{\sim}$ & $m$ & $\rightarrow$ & $\sim$ & 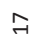 & 0 & $\rightarrow$ & $\sim$ & - & $\stackrel{n}{\sim}$ & $\vec{J}$ & 间 & $\sigma$ \\
\hline ก & $\bullet$ & & $\stackrel{\infty}{\sim}$ & & & $\sigma$ & $\stackrel{\sim}{\sim}$ & & & & & $\stackrel{m}{\neg}$ & & & $a$ & & & $\stackrel{\infty}{+}$ & in & $\stackrel{\nu}{N}$ \\
\hline I & $g$ & & $\approx$ & 0 & & & 0 & & & & & ㄱ & & & & 0 & $\stackrel{\infty}{\rightarrow}$ & & 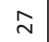 & \\
\hline$\stackrel{m}{-}$ & $\stackrel{n}{\sim}$ & & & & & & & & & & & 웅 & & & & & & $\lambda$ & $\approx$ & \\
\hline$\approx$ & n & & & & & & & & & & $\infty$ & & & $\infty$ & & & $\infty$ & $\underset{\sim}{\mathscr{C}}$ & $ং$ & \\
\hline$\exists$ & 9 & $\sigma$ & & & & & & & & $r$ & & $\stackrel{\infty}{\sim}$ & & & $\wedge$ & & & $\wedge$ & $\stackrel{m}{m}$ & $\exists$ \\
\hline ㄱ. & $\begin{array}{l}\infty \\
\infty\end{array}$ & & & & & & & & & & & $\stackrel{m}{\sim}$ & $m$ & & & & & $m$ & $\stackrel{\sim}{N}$ & \\
\hline$a$ & $\vec{\lambda}$ & & & 윽 & & & & & & & & $\stackrel{n}{\sim}$ & & & & & & & & \\
\hline$\infty$ & 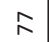 & 0 & & & & & & & & & & $\tilde{m}$ & & & & & 가 & $\approx$ & 옥 & 6 \\
\hline r & $\approx$ & & & $\stackrel{\mathscr{N}}{\sim}$ & & & $\underset{\sim}{J}$ & $\stackrel{\infty}{\sim}$ & f & & in & & & & n & & $\mathcal{\forall}$ & $\mathcal{F}$ & $\overrightarrow{6}$ & A \\
\hline 0 & $\tilde{n}$ & & & $\wedge$ & $\wedge$ & & & $\stackrel{9}{\stackrel{-}{-}}$ & & & & $m$ & & & & & & & $\stackrel{m}{\sim}$ & $\ddot{\sim}$ \\
\hline in & 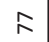 & $m$ & & & & & & & & & & & & & & & ก & $m$ & $\underset{\sim}{\Delta}$ & \\
\hline$\sigma$ & $\stackrel{\infty}{\underset{7}{7}}$ & $m$ & & 9 & & & & & & & & $\stackrel{\sim}{\sim}$ & & & & $m$ & $\hat{\sim}$ & in & 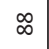 & A \\
\hline$m$ & น & & & 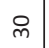 & & & & & & & & 9 & & & & & $\Phi$ & 藏 & $\widetilde{\sigma}$ & d \\
\hline$N$ & $\underset{\sim}{\tilde{m}}$ & & $\infty$ & $\stackrel{m}{\rightarrow}$ & & & $\infty$ & $\underset{\sim}{\tilde{\sigma}}$ & $\sigma$ & & $\stackrel{\sim}{N}$ & $\stackrel{\infty}{m}$ & & $\stackrel{m}{\neg}$ & $\infty$ & & $\stackrel{m}{\rightarrow}$ & $\infty$ & $\tilde{\varphi}$ & $\stackrel{m}{\rightarrow}$ \\
\hline-1 & $\stackrel{n}{\wedge}$ & & & 9 & & & & & & $m$ & & 0 & & & & $m$ & $\underset{\sim}{m}$ & & $\stackrel{\mathscr{n}}{\sim}$ & $\stackrel{-1}{0}$ \\
\hline snłełs & $\simeq$ & $\propto$ & $\stackrel{\substack{u \\
\Psi}}{4}$ & $\simeq$ & 受 & 畄 & 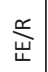 & $\propto$ & ㅆㅆㅆ & $\sum_{\underset{\psi}{W}}$ & $\propto$ & $\propto$ & $\simeq$ & $\simeq$ & $\underset{\mathrm{u}}{\stackrel{⿰}{\Psi 山}}$ & $\Sigma$ & $\Sigma$ & $\simeq$ & $\propto$ & $\Sigma$ \\
\hline
\end{tabular}

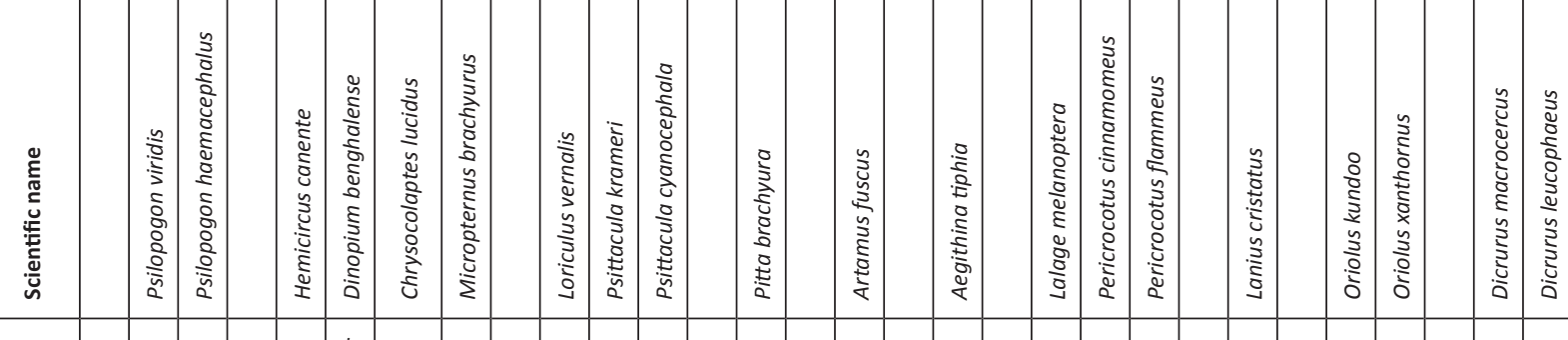

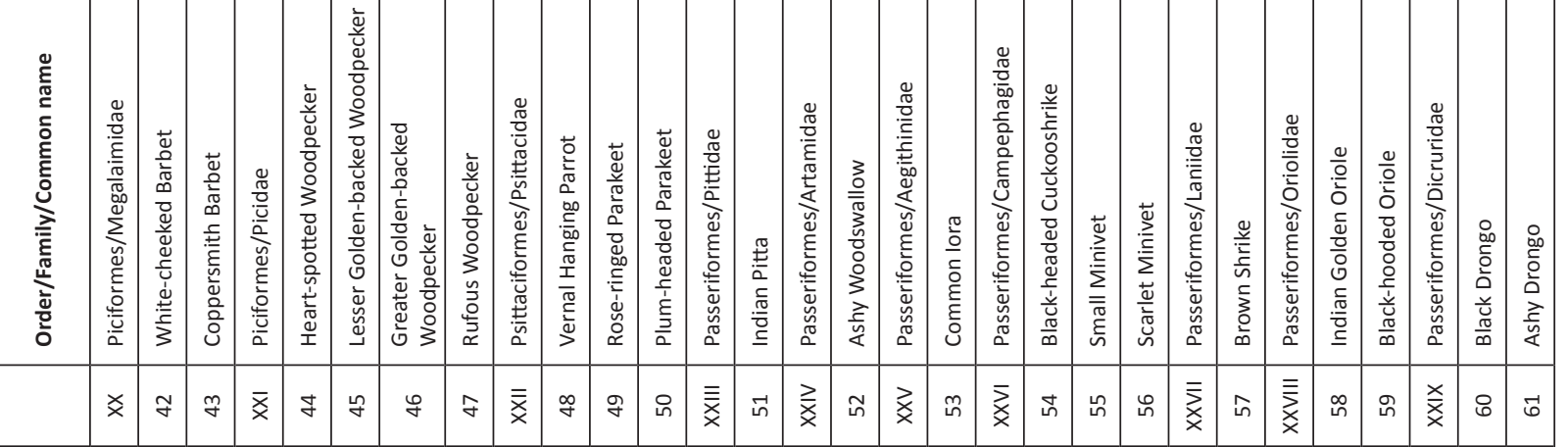




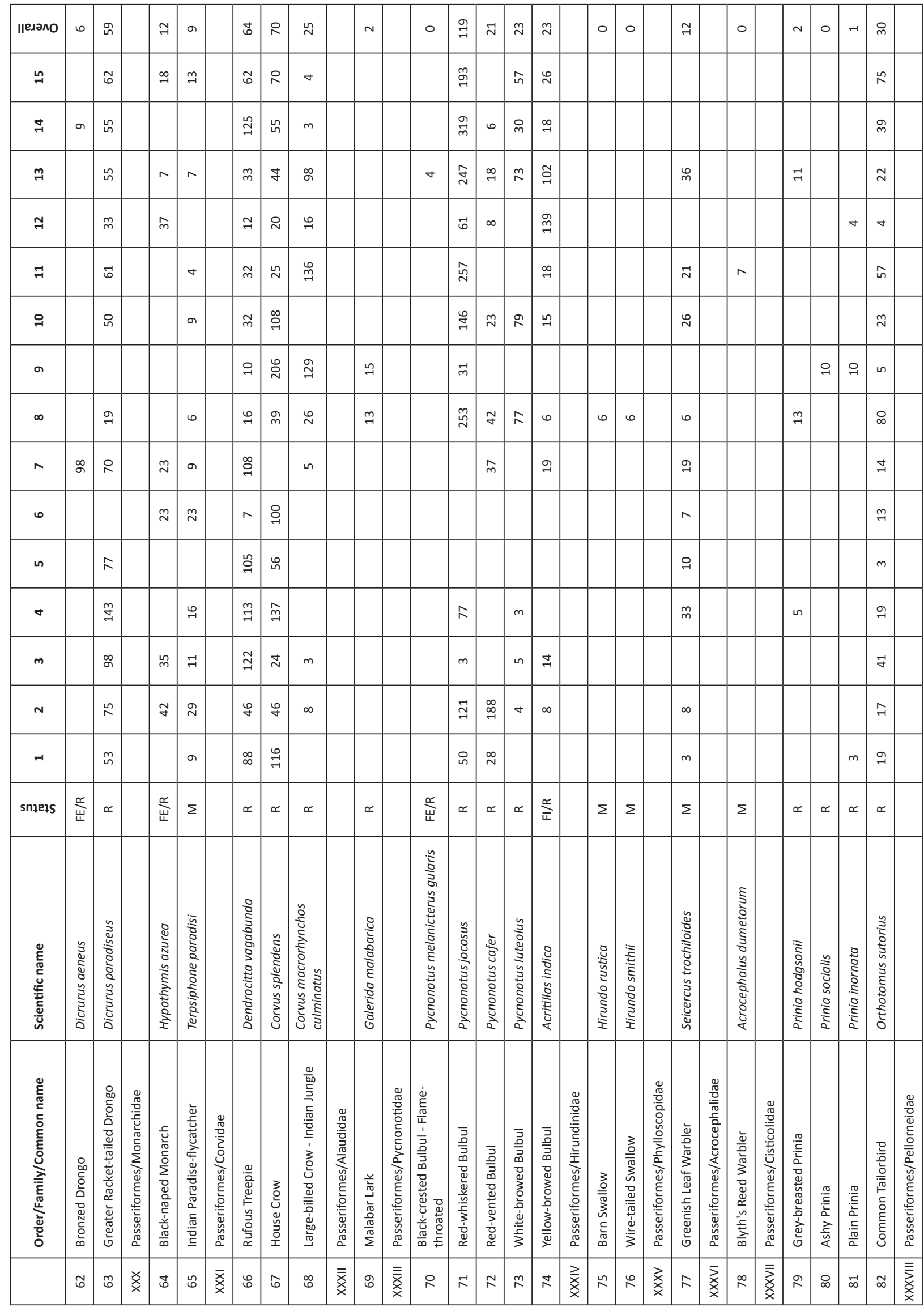




\begin{tabular}{|c|c|c|c|c|c|c|c|c|c|c|c|c|c|c|c|c|c|c|c|c|c|}
\hline ॥едәло & $\stackrel{\sim}{N}$ & 0 & 욱 & 只 & 0 & 0 & $\stackrel{\infty}{m}$ & $\infty$ & $\approx$ & 0 & $-r$ & 요 & -1 & -1 & $\sim$ & $\wedge$ & $m$ & 0 & $\overrightarrow{0}$ & $\exists$ & $\tilde{m}$ \\
\hline ก & $\vec{m}$ & $\stackrel{\infty}{\sim}$ & & & & & $\varnothing$ & & $a$ & & & $F$ & & & & $\stackrel{\sim}{m}$ & & & $\stackrel{n}{n}$ & & ذ \\
\hline I & $m$ & $q$ & $\hat{\sim}$ & $\stackrel{m}{\sim}$ & & & $\vec{N}$ & & $\approx$ & & & ก & & & 0 & $\vec{\sim}$ & $a$ & 0 & $\overrightarrow{\vec{m}}$ & $\stackrel{m}{m}$ & f \\
\hline$m$ & $\exists$ & & & & & & $\nabla$ & & $\Rightarrow$ & & & f & & & & $\stackrel{\mathscr{N}}{\sim}$ & $\nabla$ & & $\begin{array}{l}\stackrel{0}{二} \\
\exists\end{array}$ & $\stackrel{\sim}{\sim}$ & 요 \\
\hline$\approx$ & $\infty$ & & & & & & 요 & & $\sigma$ & & & $\sigma$ & & & $\infty$ & & & & $\overrightarrow{6}$ & & \\
\hline 7 & $\vec{\sim}$ & & & छे & & & & & $\exists$ & & & in & & & & & & & $\vec{\exists}$ & $\stackrel{\infty}{\sim}$ & 요 \\
\hline 욱 & $\stackrel{\sim}{\sim}$ & & & స్తి & & & R & & $m$ & & & $\approx$ & & & & & 0 & & ঃ & 0 & $\stackrel{m}{m}$ \\
\hline$a$ & & & & & & & శ్ & & & & & 오 궁 & & & & & in & & $\stackrel{\leftrightarrow}{\stackrel{\sim}{0}}$ & 욱 & $\vec{m}$ \\
\hline$\infty$ & ๖ุ & & & ㄱ. & & & $\stackrel{\mathrm{n}}{m}$ & & 0 & & & นก & & & & & & & $\infty$ & 오 & m \\
\hline r & & $\mathcal{F}$ & 㟔 & & & $\sigma$ & $\stackrel{\infty}{\sim}$ & f & in & in & & & & $\vec{G}$ & & & & & $\stackrel{\mathscr{\sim}}{\sim}$ & 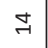 & \\
\hline 0 & & & & & & & $\wedge$ & & $m$ & & & & & & & & & & $\underset{\exists}{\stackrel{0}{二}}$ & & ్ \\
\hline in & & & & $\stackrel{\infty}{\sim}$ & & & 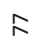 & & & & & $\vec{N}$ & $\underset{ন}{J}$ & & & & & & $\stackrel{\sim}{\exists}$ & & $\stackrel{ \pm}{\sim}$ \\
\hline$\sigma$ & F & & & $\stackrel{\infty}{n}$ & & & $\stackrel{\sim}{\sim}$ & & $\stackrel{\varphi}{\sim}$ & & & $\ddot{m}$ & & & & & $\underset{\neg}{ \pm}$ & & $\stackrel{\stackrel{n}{m}}{\vec{n}}$ & $\infty$ & $\stackrel{m}{m}$ \\
\hline$m$ & 움 & & & ్ㅗ & & & in & & $\stackrel{\sim}{m}$ & & & $\approx$ & in & & $m$ & & & & $\stackrel{\infty}{\infty}$ & n & $\exists$ \\
\hline$N$ & $\stackrel{m}{\rightarrow}$ & & & $\mathscr{6}$ & & & $\mathcal{F}$ & ஜ & in & & $\eta$ & ณ̊ & & & $\infty$ & $\mathscr{\gamma}$ & & & $\infty$ & $\stackrel{\sim}{\sim}$ & \\
\hline - & & & & & $m$ & & $\underset{\forall}{\forall}$ & & $\sigma$ & & & $\stackrel{\sim}{N}$ & & & $m$ & & & & ने & $\underset{\sim}{0}$ & a \\
\hline snłezs & $\underset{\text { 岀 }}{\stackrel{\propto}{u}}$ & 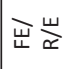 & $\propto$ & $\propto$ & 営 & 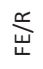 & $\propto$ & $\Sigma$ & 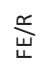 & $\frac{\mathscr{N}}{\tilde{u}}$ & $\propto$ & $\propto$ & $\sum_{i}$ & 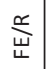 & $\underset{\sim}{\stackrel{u}{\alpha}}$ & 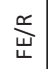 & $\propto$ & $\frac{\mathscr{x}}{\tilde{u}}$ & $\propto$ & $\propto$ & $\alpha$ \\
\hline
\end{tabular}

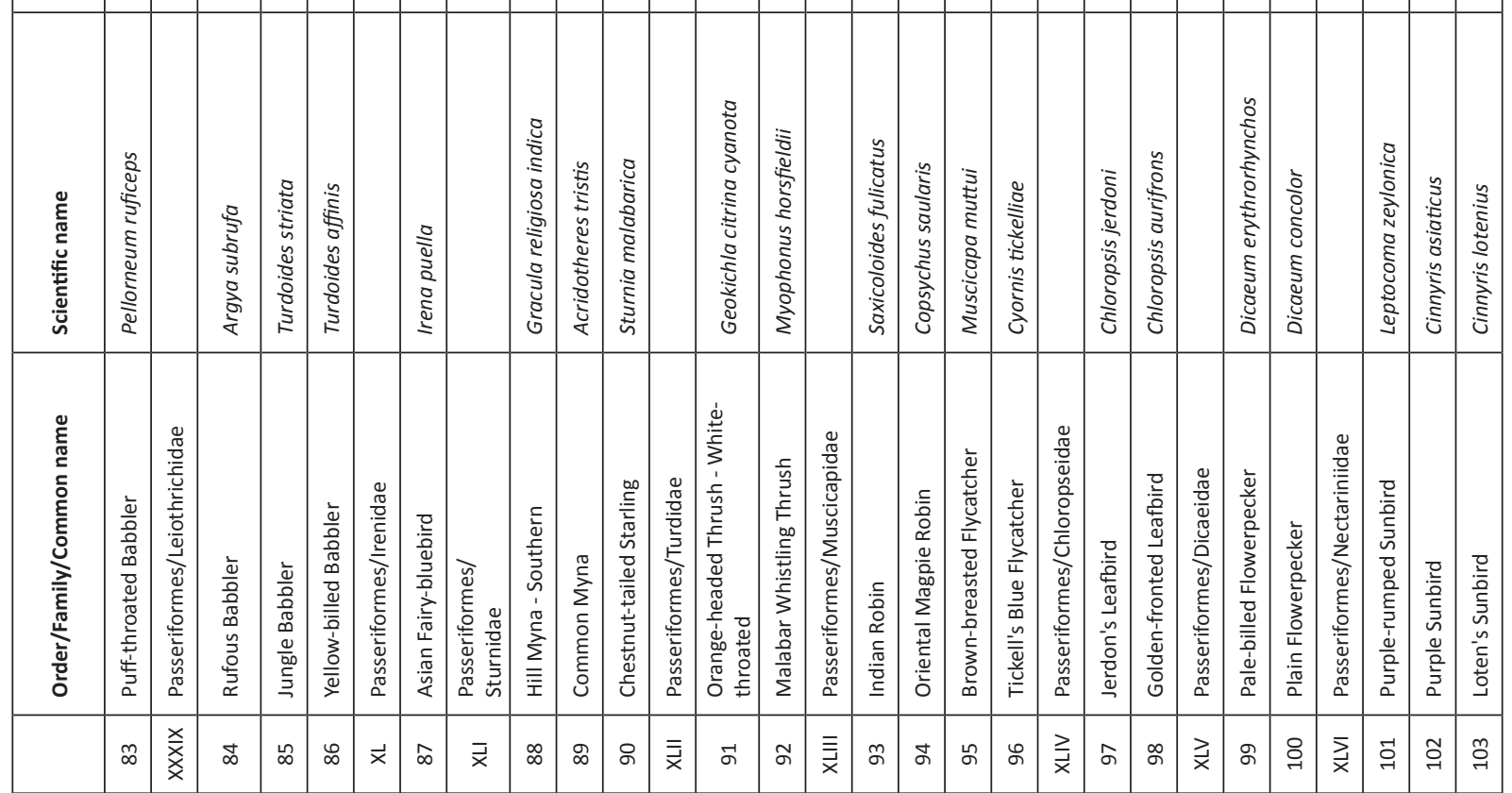




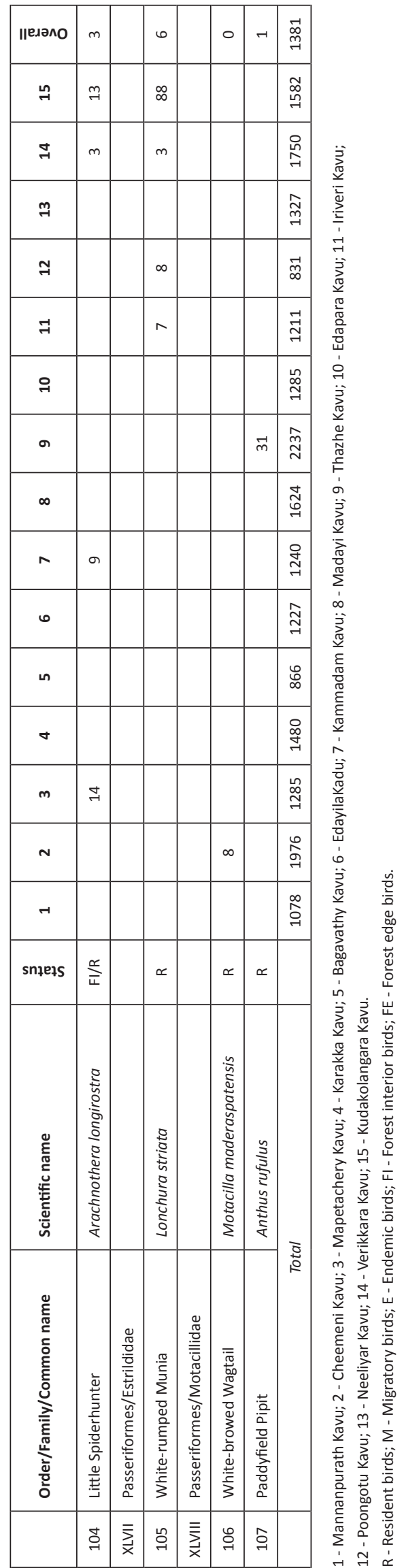

Rasmussen, P.C. \& J.C. Anderton (2012). Birds of South Asia. The Ripley Guide. Vols. 1 \& 2. Second Edition. National Museum of Natural History - Smithsonian Institution, Michigan State University and Lynx Edicions, Washington, D.C. Michigan, Barcelona.

Ripley, S.D. (ed.). (1982). A Synopsis of the Birds of India and Pakistan. Bombay Natural History Society, Mumbai.

Samati, H. \& R. Gogoi (2007). Sacred groves of Meghalaya. Current Science 93(10): 1338-1339.

Sashikumar, C. (2004). A study on the habitat quality of the sacred groves of north Kerala with birds as indicators. THANAL, Conservation Action and Information Network L-14, Jawahar Nagar, Kawdiar, Thiruvananthapuram-3.

Sashikumar, C., J. Praveen, M.J. Palot \& P.O. Nameer (2011). Birds of Kerala: Status and Distribution. DC Books. Kottayam, India, 844pp. 